\title{
Pemanfaatan Software ERP pada UMKM: Pendampingan Konfigurasi Awal
}

\author{
Stephana Dyah Ayu R. ${ }^{1}$, Robertus Setiawan Aji Nugroho ${ }^{2}$, Alexandra Adriani Widjaja ${ }^{3}$, Agnes Advensia \\ Christmastuti $^{4}$, Vena Purnamasari ${ }^{5}$ \\ 1,3,4,5, Prodi Akuntansi, Fakultas Ekonomi dan Bisnis, Universitas Katolik Soegijapranata \\ Jalan Pawiyatan Luhur IV/1 Semarang \\ stephana@unika.ac.id \\ alexandra@unika.ac.id \\ a_advensia@unika.ac.id \\ vena@unika.ac.id \\ Prodi Sistem Informasi, Fakultas Ilmu Komputer, Universitas Katolik Soegjapranata \\ Jalan Pawiyatan Luhur IV/1 Semarang \\ ${ }^{2}$ nugroho@unika.ac.id
}

\begin{abstract}
Abstrak-Usaha Mikro, Kecil dan Menengah (UMKM) memegang peranan penting dalam pengembangan perekonomian Indonesia. Menghadapi persaingan yang makin ketat, ditambah pandemi COVID-19 yang melanda seluruh dunia, sangat penting bagi UMKM Indonesia untuk memiliki informasi keuangan yang dapat diandalkan. Keterbatasan sumber daya manusia yang dimiliki UMKM adalah kendala yang menghambat pemanfaatan software Enterprise Resource Planning (ERP) di dalam bisnis mereka. Kegiatan pengabdian ini bertujuan untuk memberdayakan UMKM Indonesia dalam penyusunan laporan keuangan sederhana. Kegiatan ini dilakukan dalam bentuk pelatihan dan pendampingan penyusunan neraca awal, penyusunan basis data serta posting transaksi dengan menggunakan software Fin@count. Metode pendampingan dalam kegiatan ini lebih efektif dalam membantu para pelaku UMKM untuk memahami dan dapat menggunakan bantuan software Fin@count di dalam bisnisnya. Kegiatan ini telah diikuti oleh 10 UMKM dan melalui kegiatan ini, masing-masing UMKM telah memiliki basis data dan laporan keuangan yang memadai. Kegiatan pendampingan terbukti efektif untuk membantu UMKM dalam tahap awal implementasi software ERP. Dengan demikian para pelaku UMKM akan lebih mudah untuk melanjutkan penggunaan software tersebut. Kegiatan pendampingan ini juga melibatkan sejumlah mahasiswa S1 Program Studi Akuntansi Fakultas Ekonomi Dan Bisnis Unika Soegijapranata. Melalui kesempatan ini, para mahasiswa dapat mendapatkan kesempatan praktik
\end{abstract}

penyusunan anggaran dan laporan keuangan sederhana dalam kondisi aktual.

Kata kunci- UMKM, laporan keuangan, software, ERP, pendampingan.

Abstract-Micro Small Medium Enterprises (MSMEs to have a reliable financial information of their business. Their limited human resources has also limited their ability to utilize Enterprise Resource Planning (ERP) software even though there are plenty of ERP software available. This community service is aim to help them initialize the first stage of ERP software implementation. By this community service, 10 MSMEs are guided step by step in preparing database, calculate financial position beginning balance, and posting their transaction using Fin@count ERP Software. Step-bystep guiding method is effective to help MSMEs in understanding and utilizing ERP software. As a result, all of MSMEs participated in this project is already have their own financial statement. This result shows that this method is effective in helping MSMEs going through the initial step of ERP implementation. Thus, they can utilize the software easier. This community service also involving Undergraduate Accounting students from Faculty of Economics and Business, Soegijapranata Catholic University. This community service gave a real-world experience for the students in budgeting and financial reporting. 
Keywords-MSMEs, financial report, software, ERP, guide

\section{PENDAHULUAN}

Dua tahun belakang adalah masa sulit untuk semua bisnis, tak terkecuali UMKM. Berbagai keputusan bisnis harus dibuat secara mendadak agar mampu bertahan. Metaanalisis yang dilakukan pada UMKM di Eropa menemukan bahwa manajemen resiko keuangan merupakan variabel yang paling banyak diditeliti[1]. Hal ini menunjukan bahwa resiko keuangan merupakan hal penting yang harus diperhatikan. Kemampuan untuk mengalola resiko nantinya akan berpengaruh pada kinerja UMKM [2], [3]. Pengelolaan resiko tersebut tercermin pada pengambilan keputusan strategis yang tepat. Keputusankeputusan strategis sebuah usaha tidak akan dapat dilakukan dengan baik jika tidak didukung informasi finansial yang memadahi. Kebutuhan akan informasi akuntansi dalam pengambilan keputusan bisnis semakin meningkat. Lebih lanjut, ketersediaan informasi ini merupakan salah satu unsur penting dalam kerangka kerja pengukur Kesehatan dan keaman resiko UMKM [4]. Namun disisi lain UMKM seringkali tidak memiliki kompetensi dan kesiapan untuk menyediakan informasi akuntansi ini.

Kondisi ini menjadi perhatian kita bersama. Menjadikan UMKM sebuah usaha yang lebih baik dan siap menghadapi perubahan serta mampu menyokong perekonomian. memfasilitasi UMKM untuk mampu menyediakan informasi akuntansi minimal bagi dirinya sendiri, merupakan konsen kami yang berada didunia akademisi. Salah satu sarana mempermudah perolehan informasi adalah dengan memanfaatkan teknologi informasi. Penggunaan teknologi mampu meningkatakn efisensi dari UMKM[5]. Dengan sofware yang merupakan output dari hasil riset kami tenang kebutuhan dan kemampuan penyediaan informasi akuntansi kami berharap dapat memfasilitasi UMKM untuk lebih mudah menyediakan inforormasi akuntansi. Setelah memiliki informasi akuntansi yang memadahi diharapkan UMKM dapat membuat keputusan yang lebih baik untuk usahanya sehingga pada akhirnya akan dapat meningkatkan kinerja UMKM tersebut.

Kegiatan ini adalah kegiatan pendapingan untuk implementasi sofware akuntansi yang mudah dengan tujuan tujuan agar dapat meningkatkan kemampuan dan kesiapan UMKM dalam menyediakan informasi akuntansi guna mengefektifkan pengambilan keputusan bisnnis untuk dongkrak kinerja UMKM di wilayah Semarang yang menjadi mitra pengabdian. Pendampingan konfigurasi awal implementasi sofware akuntansi berbasis ERP ini melibatkan peran aktif mahasiswa dengan menggunakan metode service learning. Hasil penelitian sebelumnya menunjukan adanya perbedaan kemampuan mahasiswa menerima konsep dengan menggunakan metode service learning dan yang tidak menggunakan metode service learning [6]. Sehingga selain UMKM yang akan menerima manfaat dari kegiatanm ini, mahasiswa juga akan mendapatkan penagalaman berharga. Baik dalam implementasi teori yang mereka dapatkan dibangku kuliah namun juga menbgasah kemapuan sosial mahasiswa dalam berhubungan dengan masyarakat sekitarnya. Dengan menggunakan metode service learning, mahasiswa ikut terlibat dalam kegiatan bisnis UMKM. Penggunaan metode service learning akan mendorong perubahan perguruan tinggi agar lebih berperan dalam pemngembangan masyarakat[7].

\section{TINJAUAN PUSTAKA}

ERP merupakan singkatan dari Enterprise Resource Planning. Isilah ini menggabungkan tiga konsep utama yaitu perusahaan, sumberdaya dan perencanaan dalam sebuah sistem informasi. Sebuah studi metaanalisis yang dilakukan sebelumnya menunjukan bahwa perkembangan dalam riset dan praktek ERP membuat definisi ERP ini menjadi semakin meluas [8]. Pengembangan ERP agar lebih membatu perkembangan usaha masih terus dikembangkan [9]. Penerapan ERP tidak hanya terbatas pada perusahaan - perusahaan besar. Penerapan ERP dalam UMKM dapat membantu pengembangan UMKM tersebut[10].

Hasil dari penelitian - penelitian sebelumnya menunjukan bahwa ERP mampu untuk meningkatkan efektifitas kinerja sebuah kegiatan usaha[11]. Penerapan ERP untuk membantu pengelolaan persediaan telah banyak dipergunakan [12] khususnya Secara lebih spesifik penelitian [13] membuktikan bahwa ERP sangat membantu terutama dalam peningkatan pengendalian manajemen dan peningkatan manajemen kompetitif perusahaan. Keunggulan utama ERP adalah pada kemampuannya untuk mereduksi biaya dan peningkatan kualitas keputusan yang harus diterapkan,

\section{METODE}

Metode yang dipergunakan dalam kegiatan pengabdian ini adalah dengan menggunakan metode service learning. Metode service learning merupakan salah satu metode pembelajaran yang melibatkan mahasiswa dan masyarakat. Penggunaan metode servise learning dalam pembelajaran digunakan untuk mereduksi gap teori dan praktek [14]. Metode service learning menggabungkan metode pembelajaran dan pengabdian masyarakat. Masyarakat disini adalah UMKM yang menjadi mitra usaha. 
Pelaksanaan meliputi tiga tahap utama, yaitu pembelajaran di kelas, pelatihan UMKM dan pendampingan UMKM di lapangan. Terkait dengan adanya pandemic pelaksanaan service learning sebagian tahapan dilakukan dengan menggunakan e-service learning. Penggunaan e-service learning sudah cukup banyak dilakukan di perguruan tinggi [15].

Pelatihan dan pendampingan yang dilakukan adalah membantu UMKM agar dapat menggunakan sistem Finapos yang merupakan sistem pencatatan sederhana berebasis ERP. Sistem yang digunakan, merupakan sistem yang dikembangkan oleh penelitian terdahulu dari penulis. Finapos merupakan sistem yang mengakomodasi proses transasksi yang ada hinga dapat menghasilkan laporan keuangan.

Pada implementasi sistem, hambatan utama dari pengguna umumnya adalah pada saat awal implementasi atau tahap konfigurasi awal sistem. Oleh karena itu pengabdian ini memfokuskan pada konfigurasi awal. Hal ini dilakukan karena konfigurasi awal merupakan bagian yang paling sulit dalam proses penerapan ERP pada sebuah usaha. Pada proses konfigurasi awal, pengguna software harus mampu mengidentifikasi semua data yang terkait dalam usahanya, agar dapat memasukan data numerik dalam sistem ERP tersebut. Beberapa hal yang harus dilakukan adalh identifikasi semua produk yang dimiliki, identifikasi harga pokok dari setiap produk tersebut, identifikasi persediaan, identifikasi asset, tracking transaksi - transaksi yang masih belum terselesaikan dan banyak hal lain. Konfigurasi awal inilah yang nantinya memberikan dasar bagi pelaporan - pelaporan di masa yang akan dating.

\section{PEMBAHASAN}

Service learning dilakukan pada program studi akuntansi Universitas Katolik Soegijapranata. Kegiatan ini merupakan bagian dari metode pembelajaran yang diterpakan pada mata kuliah penganggaran. Partisipan yang dipergunakan adalah 50 siswa yang mengambil mata kuliah tersebut. Service learning ini merupakan proses pembelajaran yang dilakukan dengan membantu masyarakat. Outcome perkuliahan yang diharapkan adalah mahasiswa memiliki kompetensi untuk mengidentifikasi proses bisnis di lapangan kedalam pelaporan keuangan. Service learning ini diharapkan juga akan memberikan softskill kepada mahasiswa dalam hal kecermatan, kemampuan berkomunikasi dan kemampuan bekerja dalam kelompok. Proses pelaksanaan kegiatan konfigurasi awal penerapan ERP meliputi beberapa 3 tahapan seperti yang dijabarkan berikut ini.

\section{A. Pelatihan Penggunaan ERP}

Aplikasi Finapos yang dipergunakan merupakan aplikasi yang baru dikembangkan oleh peneliti. Oleh karena itu pada tahap awal penerapanannya yang dilakukan adalah memperkenalkan aplikasi ini kepada pengguna dan kepada mahasiswa yang nantinya akan mendampingi UMKM mitra tersebut. Aplikasi yang dipergunakan berbasis web sehingga bisa diakses dimana saja secara daring. Oleh karena itu proses pelatihan yang dilakukan pun berbasis daring. Pelatihan dilakuakn untuk meningkatkan pemahaman mahasiswa dan pengguna terhadap aplikasi ERP yang dipergunakan. Tahapan ini berhasil dengan baik, hal in terlihat pada kesusesan pengguna menggunakan aplikasi ERP berdasarkan data yang digunakan sebagai contoh kasus. Setelah melakukan analisis terhadap ketepatan penggunaan aplikasi tersebut maka kegiatan service learning dilanjutkan pada tahap ke dua.

\section{B. Service Learning di UMKM}

Pelaksanaan service learning, tidak dilakukan secara perorangan namun dilakukan secara berkelompok. Setiap kelompok diminta untuk melakukan identifikasi terhadap proses bisnis klien dan menyiapkan data yang diperlukan agar UMKM dapat mulai menggunakan sistem. Kebutuhan master data yang utama adalah master data produk, master data persediaan dan neraca awal. Kondisi UMKM yang minim administrasi pencatatan memunculkan tantangan bagi kelompok mahasiswa pelaksana untuk menggali informasi yang diperlukan. Kemampuan untuk berkomunikasi dan intuisi mahasiaswa berkembang pada proses melakukan wawancara dan obeservasi. Meskipun terdapat beberapa kesulitan dalam melakukan proses ini, pada akhirnya proses ini dapat diselesaikan dengan baik. Hambatan yang terjadi terutama disebabkan karena media komunikasi. Adanya kebijakan pemerintah yang memberikan stadar prosedur kesehatan sehubungan dengan pandemic Covid-19 ini membuat proses penggalian informasi Sebagian besar dilakukan secara daring. Pada proses ini tim penelitian dan pengabdian bertanggungjawab sebagai mediator jika terjadi permasalahan. Hasil wawancara dan obeservasi tersebut kemudian diterjemahkan dalam angka - angka numerik dan data yang akan diinputkan dalam ERP. Proses inilah yang disebut konvigurasi awal.

Proses belajar ini melalui service learning ini menguntungkan pihak UMKM maupun mahasiswa. Pada proses ini mahasiswa belajar mengenai bagaimana sebuah bisnis dijalankan, terkait dalam aspek keuangannya. Mahasiswa juga mempelajari local wisdom yang dianut oleh para pemilik UMKM. Pihak UMKM juga mendapatkan keuntungan yaitu mendapatkan laporan mengenai keuangan mereka, yang selama ini belum teradministrasi dengan baik. Proses belajar dengan melayani masyarakat ini diharapkan akan mampu meningkatkan sinergi antara dunia Pendidikan dan dunia usaha. 


\section{Implementasi ERP}

Pada tahap terakhir ini tim mahaiswa melakukan prosedur analisis agar dapat melakukan intrepretasi terhadap hasil wawancara dan obeservasi yang dilakukan. Proses tersebut menghasilkan data - data keuangan yang dibutuhkan seperti penentuan perhitungan harga pokok produk, penentuan persediaan yang dimiliki oleh UMKM mitra dan data keuangan yang lainnya. Hasil dari analisis tersebutkemudian dimasukan dalam aplikasi ERP yang ada. Data tersebut akan menjadi data awal bagi UMKM dalam memulai pelaporannya. Pada proses pencatan berikutnya pihak UMKM cukup melakukan input terhadap transaksi harian saja. Aplikasi akan meenghasilkan laporan keuangan yang dibutuhkan oleh pihak UMKM Mitra. Dengan menggunakan aplikasi yang disediakan tersebut pihak UMKM dapat langsung melihat hasil pekerjaan mahasiswa secara online.

Pada akhir proses kegiatan, dilakukan refleksi dan evaluasi terhadap proses yang dilakukan. Hasil evaluasi dan refleksi yang dilakukan menunjukan kebermanfaatan proses service learning dalam mengembangkan mahasiswa dan UMKM mitra.

\section{KESIMPULAN}

Pemanfaatan software ERP yang mampu mencakup kegiatan dari awal transaksi hingga pada penyusunan pelaporan keuangannya diharapkan akan membantu UMKM. ERP yang diterapkan dapat digunakan untuk mendapatkan lebih banyak informasi mengenai kondisi bisnis yang ada. Dengan menyederhanakan proses pencatatan, pemilik UMKM memiliki lebih banyak waktu untuk beerpikir strategis agar UMKM dapat semakin berkembang.

Perkembangan UMKM di Indonesia bukan hanya menjadi tanggungjawab pemerintah namun menjadi tanggungjawab seluruh bangsa Indonesia. Pengembangan untuk menjadikan UMKM semakin maju dan berkembang merupakan pekerjaan rumah bagi semua pihak baik pemerintahan, institusi Pendidikan, maupun Lembaga keuangan. Oleh karena itu pengabdian di masa datang sebaiknya dapat melibatkan lebih banyak pihak seperti penyedia dana, industry maju maupun lembaga- Lembaga lain yang mendukung. Pelibatan lebih banyak mahasiswa dengan berbagai disiplin ilmu dapat lebih memberikan pandangan baru dalam pengembangan UMKM. ERP yang sudah diterapkan saat ini baru merupakan awalan. Pendampingan dan pelatihan menganai pengambilan keputusan strageis, perencenaan bisnis masih menjadi ranah yang harus dikembangkan.

\section{UCAPAN TERIMA KASIH}

Terimakasih kami ucapakan pada pemerintah Indonesia, khususnya Kementrian Pendidikan, Kebudayaan, Riset dan Teknologi. Kegiatan pengabdian ini merupakan bagian dari penelitian Penelitian Terapan Unggulan Perguruan Tinggi. Penelitian ini merupakan salah satu skim penelitian yang didanai oleh Kemenristek Dikti untuk tahun 2021.

\section{DAFTAR PUSTAKA}

[1] P. Ferreira de Araújo Lima, M. Crema, and C. Verbano, "Risk management in SMEs: A systematic literature review and future directions," Eur. Manag. J., vol. 38, no. 1, pp. 78-94, 2020 .

[2] B. M. Pulka, A. Ramli, and M. S. Bakar, "Marketing Capabilities, Resources Acquisition Capabilities , Risk Management Capabilities, Opportunity Recognition Capabilities and SMEs Performance: A Proposed Frame work," Asian J. Multidiscip. Stidies, vol. 6, no. January, pp. 12 22, 2018.

[3] A. U. Rehman and M. Anwar, "Mediating role of enterprise risk management practices between business strategy and SME performance," Small Enterp. Res., vol. 26, no. 2, pp. 207-227, 2019.

[4] B. Kaassis and A. Badri, "Development of a preliminary model for evaluating occupational health and safety risk management maturity in small and medium-sized enterprises," Safety, vol. 4, no. 1, pp. 9-11, 2018.

[5] K. Abbasi, A. Alam, M. (Anna) Du, and T. L. D. Huynh, "FinTech, SME efficiency and national culture: Evidence from OECD countries," Technol. Forecast. Soc. Change, vol. 163, no. May, p. 120454, 2021.

[6] B. Macías Gomez-Estern, S. Arias-Sánchez, M. J. Marco Macarro, M. R. Cabillas Romero, and V. Martínez Lozano, "Does service learning make a difference? comparing students' valuations in service learning and non-service learning teaching of psychology," Stud. High. Educ., vol. 46, no. 7, pp. 13951405, 2021.

[7] L. Mortari and M. Ubbiali, "Service learning: A philosophy and practice to reframe higher education," Athens J. Educ., vol. 8, no. 2, pp. 115-138, 2021.

[8] H. Klaus, M. Rosemann, and G. G. Gable, "What is ERP?," Inf Syst. Front., vol. 2, no. August, pp. 141-162, 2000.

[9] H. A. H. Awad, "Cloud computing as an operational model for ERP services : Definitions and challenges," Int. J. Innov. Appl. Stud., vol. 8, no. 2, pp. 499-502, 2014.

[10] T. Vasiljeva, S. Shaikhulina, and K. Kreslins, "Cloud Computing : Business Perspectives, Benefits and Challenges for Small and Medium Enterprises ( Case of Latvia )," Procedia Eng., vol. 178, pp. 443-451, 2017.

[11] S. L. Indarto, S. D. A. Ratnaningsih, and S. M. D. Endah, Efektivitas Kinerja Melalui Pemanfaatan Enterprise Resource Planning (ERP) dan Customer Relationship Management (CRM). Yogyakarta: Amara Books, 2018. 
[12] A. Wiranto, M. Toha, and D. Supriyadi, "Prediksi Persediaan Minimum Dan Maximum," Kolano J. Multidiscip. Sci., vol. 1, no. 01 , pp. 55-67, 2020.

[13] M. Nawawi and D. Yunia, "Model Proses Bisnis ERP, Pengendalian Manajemen dan Keunggulan Kompetitif," $J$ Akunt. DAN BISNIS J. Progr. Stud. Akunt., vol. 7, no. 1, pp. $11-22,2021$.

[14] G. Tijsma et al., "Becoming productive 21st century citizens: A systematic review uncovering design principles for integrating community service learning into higher education courses," Educ. Res., vol. 62, no. 4, pp. 390-413, 2020.

[15] V. B. Marcus, N. A. Atan, S. M. Yusof, and L. Tahir, "A systematic review of e-service learning in higher education," Int. J. Interact. Mob. Technol., vol. 14, no. 6, pp. 4-14, 2020. 